\title{
The Implementation of Problem-Based Learning (PBL) for Environmental Education in Elementary Schools
}

\author{
(Case Study of Malang City in East Java)
}

\author{
Indriyani Rachman*,1,2 \\ ${ }^{1}$ Faculty of Environmental Engineering, ${ }^{2}$ Pascasarjana \\ ${ }^{1}$ The University of Kitakyushu, ${ }^{2}$ Universitas Pakuan Bogor \\ ${ }^{1}$ Kitakyushu, ${ }^{2}$ Bogor, ${ }^{1}$ Japan, ${ }^{2}$ Indonesia \\ *rachmanindriyani@gmail.com \\ Qiyam Maulana Binu Soesanto \\ Faculty of Environmental Engineering, \\ The University of Kitakyushu \\ Kitakyushu City, Japan
}

\author{
Toru Matsumoto \\ Faculty of Environmental Engineering, \\ The University of Kitakyushu \\ Kitakyushu City, Japan
}

\author{
Asyifa Imanda Septiana \\ PGSD Cibiru, Universitas Pendidikan Indonesia, \\ Bandung, West Java, Indonesia
}

\begin{abstract}
Formulate an environmental policy through education is important. Therefore, this study used sub-textbooks and Problem-Based Learning (PBL) methods. The subject group divided into two parts, Group $A$ and group $B$ as a control group. The results of pre-test compared to the average of group workshops with controls are: cognitive, 75.86; affective, 76.46; and behavioral, 78.45, and the experimental group are $\mathbf{6 0 . 8 5}$, 78.80, and 75.87. Comparison of N-Gain shows an increasing value from pre-test to post-test. Value of $\mathrm{N}$-Gain in the experimental class shows that the method positively increases learning outcomes.
\end{abstract}

Keywords-environmental education (EE), problem-based learning, cognitive, behavior, attitude

\section{INTRODUCTION}

Rapid economic and urban development in Indonesia has caused many serious environmental issues. As has been widely reported by the media, Indonesia has a significant plastic waste issue, making it the second worst country for plastic waste after China [1]. Plastic waste starts to pile up at river sides and around water sewers. Countermeasure acts to solve this problem are seriously needed. An important aspect in the formulation and implementation of environment policy is education, which can help citizens become people that care for the environment. This must be done actively and proactively such that actions which face environmental issues globally can be taken locally, thereby promoting positive social and economic living.
Effective environmental education policies and deepen Education for Sustainable Development (ESD) is sustainable education activities for community, one of them for educational communities. Implementation environmental education in schools and in non-formal education is necessary. Sustainable development means "balanced development of the environment, society and economy." Every person in the world, future generations and the environment are aimed to be achieving a sustainable society. Education fosters the ability to recognize life and participate in building a better society in Japan. In addition to the environment, various fields such as human rights, welfare, multicultural coexistence, and urban development has important roles. Kitakyushu City is one of the cities in Japan that conducts ESD activities.

One of the Government's initiatives to tackle environmental problems was to issue a major environmental education policy in Indonesia, called the Adiwiyata School (Green School) program. In Adiwiyata program, the level of success obtained by each school determined by the assessment team from the environmental and education agencies. Awards will give by the government to each school incorporated in the Adiwiyata program, starting from the level of city, provincial, national and the highest level is Adiwiyata Mandiri (Independent). Schools that are not yet affiliated with the Adiwiyata program has been invited by the education and the environmental agencies to participate Adiwiyata program. Whereas for schools that has been already joined the program will be given the counseling by the government to win Adiwiyata mandiri, the highest level of Adiwiyata program. Adiwiyata program conducted by the Ministry of Environment. 
However, it is difficult to determine whether the program generates positive changes in the level of environmental knowledge and awareness of students and parents, or whether the implementation of school development and educational programs changes children's behavior. There is a big difference between schools in big cities and schools in the regions. There are also those who are skeptical about the effectiveness of the program. On the other hand, in Malang City and Batu City in East Java Province, changes in the level of knowledge, attitudes, and awareness of students have taken place in relation to environmental education (EE), as evidenced from the ESD environmental testing program conducted by Matsumoto and Indriyani [2]. EE research by utilizing PBL method in elementary school in eight cities in Indonesia have certified Adiwiyata schools. In particular, changes in the teachers have been extraordinary. Developments have been made to design teaching materials according to the actual conditions of the environment in which students are located, which also creates changes in children. Therefore, in this study, we trialed the ESD program using the problem-based learning model for environmental care [3] in the ESD participatory environment that has been improved and developed based on the local context of Malang City.

Previous studies regarding learning by PBL method have shown that if the objectives we choose in science education are inclusive and are intended to improve student learning achievement, then we must identify teaching methodologies that are appropriate for teaching and learning specific knowledge [4]. The findings from this study show that PBL and Environmental education (EE) methodologies are beneficial for teachers and students. Clarifying the effectiveness of environmental education program trials based on PBL to teachers and eight elementary school student in Batu city and Malang city.

Students' skills in solving environmental problems, especially in the environment around schools, homes, and river basins can be supported by the application of PBL models. Besides the application of PBL learning models, environmental education training can develop the interest of $96 \%$ of students in reducing waste by recycling plastic waste into useful items [5]. However, research on the application of an environmental education curriculum at Madara Kamaraj University in Tamil Nadu found that there is no strong relationship between environmental behavior and skills in solving environmental problems [6]. For this reason, more concrete efforts are needed to increase overall environmental awareness. One way is to implement PBL methods in Environmental education (EE) subjects that are able to continuously improve knowledge, attitudes, behavior, and skills. Following the results of previous studies, the intention of the researchers was to examine closelyrelated efforts to raise the level of knowledge, attitude, and behavior of students. The aims of this study were therefore to test the effects on students and the changes in teaching patterns of teachers who try the PBL program by using local textbooks and learning methods via activity worksheets used by elementary schools in Kitakyushu city in Japan as an environmental friendly city.
In the EE learning pilot study, EE textbooks used for primary schools in Malang city and surrounding cities, whereas worksheets with PBL methods commonly used for elementary schools in Kitakyushu city have been translated into Indonesian by following local wisdom of Malang city.

\section{Methods}

\section{A. Study Area}

This trial was conducted in the Malang city, located in East Java province Indonesia. Malang has a population of 895,387 and an area of $145.28 \mathrm{~km} 2$ [7]. One of the reasons why there is much concern regarding environmental aspects in Malang is because this city is a local tourist destination in East Java. The city government is also very concerned with creating environmentally friendly schools. In 2020, 173 schools (both elementary and junior high schools) in Malang City already have status as Adiwiyata schools [8]. This study collected data from 4 Adiwiyata schools and 4 non-Adiwiyata schools.

\section{B. Sampling Methodology and Data Sampling}

This study involved experimental research in grades 4 and 5 of each elementary school. A pre- and post-test design, with an experimental and a control group of Adiwiyata and nonAdiwiyata schools, respectively, was used. This study's objective was to examine the effect of learning with the use of EE textbooks accompanied by PBL worksheet of kitakyushu city and environmental education learning in increasing the environmental awareness of elementary school students. In the first stage, this research determines the experimental class and the control class, then employs pre-tests at the beginning of the meeting using the environmental awareness instruments in the EE (Environmental education) textbook. The second stage was to give workshops to teachers in the experimental class. The workshops were held four times per year and applied the PBL method. In the control class, conventional learning was applied. The third stage involved conducting a final evaluation (posttest) with the same test questions. The last stage involved analyzing the pre-test and post-data data using t-test, N-Gain analysis, and cluster analysis. The covariate variable is environmental awareness with the following sub-variables: students' cognitive, affective, and behavioral learning skills, and their skills in solving environmental problems.

\section{Examination and Verification of Methods for Measuring ESD Environmental Effects}

ESD is one of the most efficient methods of implementing sustainable development principles because it is capable of forming new patterns of thinking and behavior. To verify the effectiveness of the environmental ESD program [9], an effectiveness test and survey questionnaires were carried out for elementary schools in Malang. The questionnaire was made based on the PLH curriculum and PLH textbooks used by elementary schools in Malang. In measuring its impact of ESD program in schools for students and teachers. In addition to the five recommendation items of Tbilisi UNESCO (recognition, 
knowledge, attitudes, skills, and participation) [10] were used. Indicators were determined by reference to the SDGs (Sustainable Development Goals).

\section{This Measurement used the Following Calculation Method}

- Counting with regression to see changes before and after the teacher was given additional knowledge about EE learning methods used in Kitakyushu city elementary schools. EE textbooks used in Malang and worksheets used by elementary school students in Kitakyushu City that have been translated were used.

- Cluster analysis was used to see the overall changes before and after the trial.

\section{E. Interview and Teacher Awareness Survey}

Interview has been conducted to teachers about the measurement results changes in student behavior before and after the ESD environmental material test using the PBL method in elementary schools in Malang city and Batu (Certified Adiwiyata elementary schools and non- Adiwiyata elementary schools). The awareness survey focuses on teachers' awareness before and after the experiment. Questionnaires and interviews about awareness and skills from the point of view of professional development, and verification of teacher awareness and behavior change were carried out. To improve the program, exchange views with joint researchers (Malang University) and examine local environmental issues were conducted.

\section{F. Interview with the Principal: The Role of ESD in Model Schools}

The process of building an ESD network environment involves role sharing and coordination of each schools. This involved the promotion of environmental ESD activities and arranging interviews with schools and related schools to clarify the process of building networks among schools in the Malang region and the functions of sharing roles and the coordination of each schools.

\section{G. Interview and Teacher Awareness Survey}

Interview has been conducted to teachers about the measurement results changes in student behavior before and after the ESD environmental material test using the PBL method in elementary schools in Malang city and Batu (Certified Adiwiyata elementary schools and non- Adiwiyata elementary schools). The awareness survey focuses on teachers' awareness before and after the experiment. Questionnaires and interviews about awareness and skills from the point of view of professional development, and verification of teacher awareness and behavior change were carried out.

\section{H. Sample and Instrument}

1) Survey process. Table. 1 shown number of detail regarding the schools and students involved in this research.

TABLE I. TRIAL ELEMENTARY SCHOOLS

\begin{tabular}{|c|c|c|c|c|}
\hline \multirow[b]{2}{*}{$\begin{array}{l}\text { Adiwiyata } \\
\text { school }\end{array}$} & \multicolumn{2}{|c|}{ Text book and Worksheet } & \multicolumn{2}{|c|}{$\begin{array}{c}\text { Without Text and } \\
\text { Worksheet }\end{array}$} \\
\hline & $\begin{array}{l}\text { Elementery } \\
\text { School A1 }\end{array}$ & $\begin{array}{l}\text { Elementery } \\
\text { School A2 }\end{array}$ & $\begin{array}{l}\text { Elementery } \\
\text { School A3 }\end{array}$ & $\begin{array}{l}\text { Elementery } \\
\text { School A4 }\end{array}$ \\
\hline $\begin{array}{l}\text { Non } \\
\text { Adiwiyata } \\
\text { School }\end{array}$ & $\begin{array}{l}\text { Elementery } \\
\text { School NA1 }\end{array}$ & $\begin{array}{l}\text { Elementery } \\
\text { School } \\
\text { NA2 }\end{array}$ & $\begin{array}{l}\text { Elementery } \\
\text { School NA3 }\end{array}$ & $\begin{array}{l}\text { Elementery } \\
\text { School } \\
\text { NA4 } \\
\end{array}$ \\
\hline
\end{tabular}

In the first field survey 2019 November, we visited schools that would participate in this study to distribute questionnaires and conduct interviews with principals and teachers who has been involved in the research. For the group of teachers who will took part in the workshop, how to use the textbooks and the PBL method worksheets was explained; for teachers in the non-workshop group, no textbooks or worksheets were given. EE textbooks are usually used daily in EE learning. At the workshop, the textbooks and worksheets suitable for students in grades 4 and 5 were demonstrated. Based on the results of the first survey, the content of the ESD environmental teaching materials for students was adjusted based on regional characteristics. Tests to confirm prior knowledge about students' cognitive, affective, and behavioral learning, and environmental awareness surveys (before the implementation of participatory environmental ESD programs) were conducted.

\section{RESUltS AND DisCUSSION}

Pre- and post-test results from the eight researched classes were analyzed using statistical tests. The analyzed data were pre-test, post-test, and gain scores from the two study groups. Precondition analysis of the data collected was undertaken using the Kolmogorov-Smirnov and Shapiro-Wilk tests for normality, while Levine's test was used for homogeneity. Besides that, analysis of covariance (ANCOVA) was used to test the hypotheses, i.e., to find out whether there is an effect of applying PBL models on students' environmental awareness. This consisted of two initial hypotheses which were either accepted or rejected. All analysis was performed using SPSS software version 23.0 for Windows. Initial data processing was conducted to test the normality and homogeneity of the data at the 0.05 significance level. The results of data analysis show that the data are normally distributed $(\mathrm{p}=>0.05)$, while the homogeneity test using Levine's test shows that the data were homogeneous $(\mathrm{p}=0.142,>0.05)$, as shown in Table 2 . 
TABLE II. THE RESUlTS OF THE EXPERIMENTAL AND CONTROL GROUP PRE-TEST

\begin{tabular}{|l|l|l|l|}
\hline \multicolumn{5}{|c|}{ Textbook and Worksheet Group } \\
\hline Name of School & Cognitive & Affective & Behavior \\
\hline Elementary School Class 4 A2 & 80.6 & 82.3 & 81.6 \\
\hline Elementary School Class 5 A2 & 75.3 & 77.1 & 79.3 \\
\hline Elementary School Class 4 A1 & 70.3 & 76.3 & 71.8 \\
\hline Elementary School Class 5 A1 & 73.7 & 76.3 & 75.5 \\
\hline Elementary School Class 4 NA4 & 68.9 & 75.3 & 77.5 \\
\hline Elementary School Class 5 NA4 & 68.3 & 77 & 77 \\
\hline Elementary School Class 4 NA4 & 76.8 & 81.2 & 76.8 \\
\hline Elementary School Class 5 NA4 & 73.8 & 81.3 & 78.5 \\
\hline \multicolumn{4}{|c|}{ Without Texbook and Worksheet Group } \\
\hline Elementary School Class 4 A4 & 86.3 & 74.8 & 79.9 \\
\hline Elementary School Class 5 A4 & 71.3 & 85.5 & 87 \\
\hline Elementary School Class 4 A3 & 82.9 & 77 & 81.7 \\
\hline Elementary School Class 5 A3 & 77.9 & 80.4 & 82 \\
\hline Elementary School Class 4 NA4 & 73.8 & 74.8 & 73 \\
\hline Elementary School Class 5 NA4 & 71.7 & 75.3 & 75.7 \\
\hline Elementary School Class 4 NA3 & 73.9 & 80.8 & 78.6 \\
\hline Elementary School Class 5 NA3 & 75.9 & 78.6 & 78.2 \\
\hline
\end{tabular}

\section{Data Recapitulation of Pre- and Post-test Results}

Table 3 shows that the mean value of the control class pretest is higher in each aspect than the pre-test value of the experimental class. However, based on the standard deviation values, indicated by lines on each bar in the Fig. 2, the distance distribution of values in the control class is higher than that in the experimental class. This means that in the control class, students' scores are more diverse than in the experimental class. The lowest score in the control class is lower than the experimental class's lowest score. The mean score in the control class is higher than that of the experimental class because the highest score in control class is higher than the highest score in the experimental class. The mean value of the post-test result in the experimental class is higher than the mean value of the control class in all aspects. This is inversely proportional to the results of the pre-test previously described. In cognitive and affective aspects, the distribution of control class values is higher than that of the experimental class. Nonetheless, this still makes the mean value of the control class lower than that of the experimental class. Meanwhile, in the aspect of behavior, the mean value obtained by the experimental class is much higher than that of the control class. In addition, the upper range of the distribution of control class behavior values is also lower than the distribution of experimental class values.

\section{A. T-test Pre-test and Post-test Results}

The t-test scores for cognitive, affective, and behavioral aspects are less than 0.005 . Thus, there is a significant average score difference between the experimental and control groups (Table 3).
TABLE III. Pre-Test And Post-Test Results of The ExPERIMENTAL AND CONTROL GROUPS

\begin{tabular}{|l|l|l|l|}
\hline & & \multicolumn{1}{|c|}{ Experiment } & Control \\
\hline \multirow{4}{*}{ Pretest } & Cognitive & 60.86 & 75.87 \\
\cline { 2 - 4 } & Affective & 68.39 & 76.46 \\
\cline { 2 - 4 } & Behavior & 75.87 & 78.46 \\
\hline \multirow{4}{*}{ Posttest } & Cognitive & 83.54 & 83.13 \\
\cline { 2 - 4 } & Affective & 81.54 & 80.94 \\
\cline { 2 - 4 } & Behavior & 89.4 & 84.46 \\
\hline N-Gain & Cognitive & 57.97 & 21.59 \\
\cline { 2 - 4 } & Affective & 37.88 & 14.97 \\
\cline { 2 - 4 } & Behavior & 52.46 & 25.01 \\
\hline
\end{tabular}

\section{B. $N$-Gain Result (Increment)}

The N-Gain score results shown in Figure 1 indicate that there is a score increment from pre- to the post-test. The high $\mathrm{N}$-Gain value in the experimental class shows that the method used has a positive effect on learning outcomes. In this study, all aspects of learning showed rapid improvement in the experimental class.

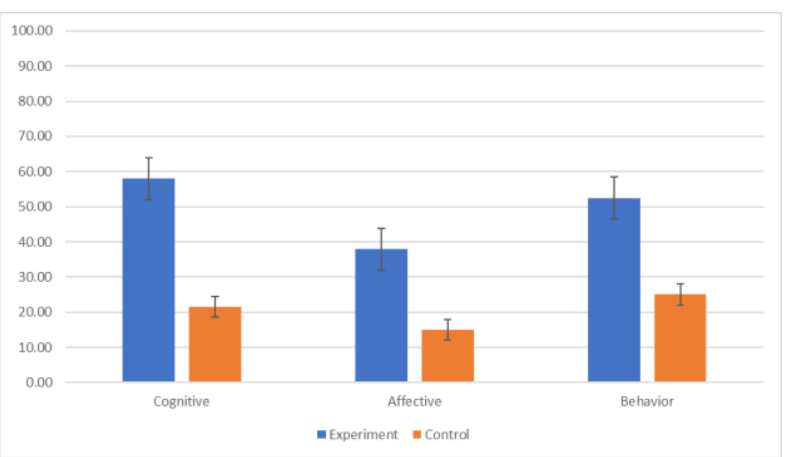

Fig. 1. Comparison of N-Gain values of the experimental and control groups.

\section{T-Test for Control Class}

Significant differences in $\mathrm{N}$-Gain values indicate that there are differences in learning outcome using PBL (Problem Based Learning) method compared to conventional classes. This shows that the learning methods used in the experimental class effectively improve learning outcomes.

\section{Cluster Analysis to Determine Group Condition}

\section{1) Control class cluster analysis}

TABle IV. Cluster Results for the Control Class Pre- AND POST-TEST

\begin{tabular}{|l|c|c|c|}
\hline \multicolumn{4}{|c|}{ Cluster Control Class } \\
\hline & $\mathbf{1}$ & $\mathbf{2}$ & $\mathbf{3}$ \\
\hline Prestest Cognitive (PreCo) & 68 & 87 & 70 \\
\hline Affective Pretest (PreAf) & 79 & 79 & 72 \\
\hline Pretest Behavior (PreBe) & 83 & 80 & 74 \\
\hline Post Cognitive (PosCo) & 83 & 89 & 77 \\
\hline Posstest Afective (PosAf) & 82 & 84 & 77 \\
\hline Posstest Behabior (PosBe) & 91 & 86 & 79 \\
\hline
\end{tabular}


All data in the control class were divided into three clusters using the K-mean method, as shown in Table 4. From the results of this clustering, we can discern three groups with the following characteristics. Cluster 1 contains data with the lowest average cognitive pre-test score compared to the average cognitive pre-test score in the other clusters. This cluster 1 has the highest average behavioral score compared to other clusters, as well as the post-test score of its behavioral aspect. The increase in the mean score of Cluster 1 can also be said to be significant when looking at the difference in the mean cognitive and affective pre- and post-test scores. Cluster 2 has the highest average pre-test and post-test cognitive and affective post-test score was also the highest compared to that of the other clusters, even though the affective pre-test score was the same as that of Cluster 1. Meanwhile, other scores are at the mid-level when compared to other cluster scores. Cluster 3 has the lowest score compared to other clusters in all aspects. However, there is an increase in the average score of the pretest compared to the final post-test score, which indicates progress.

\section{E. Experimental Class Cluster Analysis}

TABLE V. Cluster RESUlts FOR THE EXPERIMENTAL Class PRE- AND POST-TEST

\begin{tabular}{|l|c|c|c|}
\hline \multicolumn{4}{|c|}{ Cluster Experimental Class } \\
\hline & $\mathbf{1}$ & $\mathbf{2}$ & $\mathbf{3}$ \\
\hline Pretest_Kognitive (PreKo) & 54 & 46 & 70 \\
\hline Pretest_Affective (PreAf) & 70 & 70 & 67 \\
\hline Pretest_Behavior (PreBe) & 77 & 71 & 76 \\
\hline Postest_Kognitive (PosKo)_ & 73 & 75 & 93 \\
\hline Posttest_Afective (PosAf) & 79 & 81 & 83 \\
\hline Posttest_Behabior (PosBe) & 94 & 72 & 91 \\
\hline
\end{tabular}

The experimental class cluster analysis data are shown in Table 5. Similar to the control class, the data are also classified into three clusters with different characteristics, as follows. Cluster 1 has the highest pre- and post-test behavioral scores compared to the other two clusters, while scores in other aspects are at the mid-level. The pre-test cognitive score in Cluster 1 is higher than that of Cluster 2, otherwise the posttest cognitive score of Cluster 2 is higher than Cluster 1 . In addition, the pre-test affective score in Cluster 1 is the same as that in Cluster 2, but the affective post-test score in Cluster 1 is not as high as the affective post-test score of the cluster 2. Even the affective aspects of the post-test value in Cluster 3 are higher than that of Cluster 1, even though the pre-test score in Cluster 3 is initially lower.

From these findings it can be concluded that Cluster 1 contains groups of students who have succeeded in improving their learning in the behavioral aspect, while the other aspects of learning progress are not as high even though they are not negative. Otherwise, Cluster 2 has the lowest cognitive pre-test score, nevertheless the post-test cognitive aspect value did successfully advance such that Cluster 2 did not attain the lowest cognitive post-test score. Affective aspects also demonstrated a similar increment. Although the affective aspect pre-test score in Cluster 2 has the same as Cluster 1, post-test score indicates greater progress compared to Cluster 1. Cluster 2 has the lowest score in the behavioral aspect of both pre-and post-tests. There is no rapid progress in the behavioral aspect of cluster 2 . It can be concluded that Cluster 2 is inversely proportional to Cluster 1 , which only succeeded in the behavioral aspect. Although Cluster 2 achieved none of the highest scores, it succeeded in increasing cognitive and affective aspect scores better than Cluster 1. Cluster 3 contains data with better results compared to the other clusters 1 and 2 although the post-test behavior value is not as good as Cluster 1. The cognitive and affective aspects in Cluster 3 has the better result than the other two clusters, although the pre-test score of the affective aspect is the least good. It can be concluded that the students in cluster 3 succeeded in improving all aspects of learning.

\section{F. Teacher Interview Results}

The teachers who teach EE understand more about behavioral awareness in the surrounding environment. Current interview stage results indicate that teachers who have an interest in PLH and changing awareness and behavior (especially regarding the professional development of teachers related to the way they teach) affect teacher awareness regarding environmental ESD and professional teacher development, whether they are in an Adiwiyata-certified school or a non-Adiwiyata certified school. In the pre-program implementation phase, there is a significant need to acquire knowledge and information about environmental ESD and improve teaching skills, but in the implementation process, the position of environmental education in the curriculum has a different effect on teacher awareness. There are differences in environmental ESD awareness prior to program implementation, depending on the school and whether the teacher is in an Adiwiyata-certified school or not. Some teachers in schools that are not certified assume that one of the requirements of "Adiwiyata certification" is the necessity to promote environmental ESD. Interviews with teachers used green note after experiment shown in Table 6. 
TABLE VI. INTERVIEW WITH TEACHERS AFTER THE EXPERIMENT USING ESD EE WORKSHEET

\begin{tabular}{|c|c|c|c|c|c|}
\hline \multirow[b]{2}{*}{ No } & \multirow{2}{*}{$\begin{array}{l}\text { Use worksheet in } \\
\text { School Evaluation }\end{array}$} & \multicolumn{2}{|c|}{ Adiwiyata School } & \multicolumn{2}{|r|}{ Non Adiwiyata School } \\
\hline & & A1 & $A 2$ & NAI & $\mathrm{NA2}$ \\
\hline 1 & $\begin{array}{l}\text { Did you use the } \\
\text { worksheet in learning } \\
\text { environmental } \\
\text { education (during the } \\
\text { program) }\end{array}$ & $\begin{array}{l}\text { Used after the workshop, } \\
\text { integrated with other subjects. } \\
\text { All the themes and methods in } \\
\text { the book have been carried } \\
\text { out. Used cardboard made for } \\
\text { trash. Making organic } \\
\text { fertilizer. Glass bottles used as } \\
\text { flower vases. Class } 4 \text { science } \\
\text { lessons }\end{array}$ & $\begin{array}{l}\text { In Kota Batu, there is a curriculum } \\
\text { of its own, for grade } 4 \text {, There is a } \\
\text { theme of diversity. Because EE is } \\
\text { integrated with other subjects. For } \\
\text { variety, learn to use green note, } \\
\text { schools work together with the } \\
\text { garbage bank. Students are invited } \\
\text { to sort trash, the trash is used by } \\
\text { the class. worksheet helps to be a } \\
\text { learning medium }\end{array}$ & $\begin{array}{l}\text { Only channels } 1 \text { and } \\
2 \text { only }\end{array}$ & $\begin{array}{l}\text { EE curriculum already exist, in one week } 2 \\
\text { lessons hours, the green note book helps in } \\
\text { making it easier to deliver EE lessons. } \\
\text { Students become motivated and enthusiastic, } \\
\text { especially when using games. At first } \\
\text { students were not motivated to learn EE, but } \\
\text { after using the worksheet, students became } \\
\text { changes in knowledge and behavior. In the } \\
\text { worksheet there are experiments and } \\
\text { learning activities. }\end{array}$ \\
\hline 2 & On any subject & $\begin{array}{l}\text { It's easier and students } \\
\text { become interested, they enjoy } \\
\text { learning while playing }\end{array}$ & $\begin{array}{l}\text { With EE again, not much has been } \\
\text { used }\end{array}$ & On science & All subject \\
\hline 3 & $\begin{array}{l}\text { What subjects are } \\
\text { integrated }\end{array}$ & $\begin{array}{l}\text { Worksheets are used by } \\
\text { teachers and children are } \\
\text { very happy }\end{array}$ & $\begin{array}{l}\text { Maching of textbooks and } \\
\text { worksheets. Per chapter the } \\
\text { same. Guide book }\end{array}$ & $\begin{array}{l}\text { Concentration } \\
\text { teaches } \\
\text { learning other than } \\
\text { EE }\end{array}$ & $\begin{array}{l}\text { The use of green notes supports } \\
\text { explanations in textbooks, then } \\
\text { teaches using worksheets }\end{array}$ \\
\hline 4 & $\begin{array}{l}\text { Is it easier to teach } \\
\text { students? }\end{array}$ & $\begin{array}{l}\text { Elementary schools in Malang } \\
\text { are all integrated subjects, } \\
\text { there are no EE subjects } \\
\text { specifically, so the use of } \\
\text { worksheet and EE textbooks is } \\
\text { only a resource to be } \\
\text { associated with other subjects }\end{array}$ & Easier to understand & $\begin{array}{l}\text { Students love play } \\
\text { games }\end{array}$ & Varied, easier and varied \\
\hline
\end{tabular}

\section{CONCLUSION}

Based on the discussion of research results, it can be concluded that the average value of the experimental class applying the learning model using textbooks and PBL worksheets demonstrates greater change in cognitive, affective, and behavioral learning aspects, as well as the skills in solving environmental problems compared to the control group to whom the conventional learning model was applied. Thus, the PBL model is able to internalize knowledge and skills to solve environmental problems and to develop positive attitudes and behaviors toward the environment in elementary school students. It is important to issue effective environmental education policies and deepen ESD in environmental education in schools. To enhance positive changes in the level of environmental knowledge and student awareness, school development programs and PBL methods for teaching EE, that have been developed based on the context of local wisdom, should be applied. This will also enhance teachers' abilities, increase knowledge, and increase student awareness about environmentally friendly lifestyles. PBL methods in EE learning about rivers and water, usually carried out by elementary school teachers in the city of Kitakyushu, showed an increase in the grades of the experimental class. This shows that the method positively improved learning outcomes. In this study, all aspects of improved learning were developed in the experimental class. The t-test values of cognitive, affective, and behavioral aspects were less than 0.005 , which means that the difference between the experimental and control groups is significant. The significant difference in the $\mathrm{N}$-Gain values also indicate the difference in results using the experimental method compared with the conventional method. This shows that the learning methods used in the experimental class effectively improved learning outcomes.

These of EE books in the implementation of learning should be accompanied by a worksheet that can increase student enthusiasm for learning in combination with the PBL method. The teacher's ability to give lessons is also very influential on student learning success. Another aspect of achieving Adiwiyata status in schools is to increase school community awareness of the importance of environmental ESD prior to program implementation. However, this depends on headmaster policy each school, whether the school will participate in the Adiwiyata program or not. Teachers who teach in non-Adiwiyata schools usually consider the implementation of the program to be rather difficult because it is considered in terms of the facilities that must be provided. However, environmentally friendly schools do not require luxurious physical facilities. This misperception causes some schools to feel unable to achieve Adiwiyata certification. In fact, collaboration with school communities who have the right knowledge, attitudes, and behavior will help to change the school into an environmentally friendly school.

\section{REFERENCES}

[1] A.H. Tullo, "Fighting ocean plastics at the source," Chemical \& Engineering News, vol. 96, no. 16, pp. 29-34, 2018.

[2] I. Rachman and T. Matsumoto, "PBL Method under the environmental education in Indonesia analyzing the influence of PBL Method into the knowledge attitude and behavior aspects," IOP Conf. Ser. Earth Environ. Sci., vol. 245, no. 1, 2019.

[3] M. Kuvac and I. Koc, "The effect of problem-based learning on the environmental attitudes of preservice science teachers," Educ. Stud., pp. 1-23, Mar. 2018 
[4] Y. Karagiorgi and L. Symeou, "Translating Constructivism into Instructional Design: Potential and Limitations," Educ. Technol. Soc., vol. 8, pp. 17-27, 2005.

[5] T.T. Phan Hoang and T. Kato, "Measuring the effect of environmental education for sustainable development at elementary schools: A case study in Da Nang city, Vietnam," Sustain. Environ. Res., vol. 26, no. 6, pp. 274-286, Nov. 2016.

[6] M. Sivamoorthy, R. Nalini, and C.S. Kumar, "Environmental Awareness and Practices among College Students," Int. J. Humanit. Soc. Sci. Invent., vol. 2, no. 8, pp. 11-15, 2013.
[7] BPS Kota Malang, "Jumlah Penduduk di Kota Malang Menurut Kecamatan dan Jenis Kelamin, 2011-2020,” 2020. .

[8] R. Malang, "Radar Malang." .

[9] A. Nasibulina, "Education for Sustainable Development," 2017, pp. 947-954.

[10] R.B. Stevenson, M. Brody, J. Dillon, and A.E.J. Wals, Eds., International Handbook of Research on Environmental Education. Routledge, 2013. 